\title{
Methyl bromide fumigation versus other ways to prevent the spread of mushroom virus disease
}

\author{
Annemarie Dieleman-van Zaayen \\ Institute of Phytopathological Research (IPO), Wageningen, the Netherlands
}

Received: 20 April 1971

\section{Summary}

A virus disease has been a considerable threat to the rapidly growing mushroom industry in the Netherlands. Intensive research has been done to control this disease, which spreads by mycelium and spores from infected mushrooms.

The action of methyl bromide in the gas phase was studied, and compared with current chemicals and control methods. Mushroom spores appeared to be destroyed at relatively low dosages of methyl bromide; they were also readily killed, however, by a short treatment with formaldehyde vapour. It was already known that this can be achieved by a short heat treatment $\left(1 \mathrm{~h} \mathrm{at} 70^{\circ} \mathrm{C}\right)$. The results of methyl bromide fumigation of mycelium, spawn, contaminated growing trays and compost permeated with mycelium were disappointing. Various mycelial isolates differed in sensitivity to methyl bromide.

Thus methyl bromide fumigation cannot replace the traditional after-crop cookingout of mushroom houses with live steam, followed by treatment of the wood with sodium pentachlorophenate.

\section{Introduction}

A virus disease of cultivated mushrooms

In recent years the Dutch mushroom farming has suffered severe losses. They are duc to a virus disease of the cultivated mushroom (Agaricus bisporus (Lange) Sing.), first recognized in this country in 1964. Crop yield is seriously reduced and the few mushrooms formed are misshapen (Dieleman-van Zaayen, 1969).

A survey among the more than 1,000 Dutch growers showed that in 1967 and the first half of 1968 , one out of three mushroom farms was contaminated; on these farms average crop loss was $15 \%$. Thus in 1967 , in total $4.5 \%$ (or about $790,000 \mathrm{~kg}$ ) of the production, which amounted to 17.5 million $\mathrm{kg}$ mushrooms, was lost.

The disease concerned was first observed in America in 1948 (Sinden and Hauser, 1950) and further described in England by Gandy (1960). Later it was named 'Dieback disease'. Hollings (1962) showed that different types of virus particles can be isolated and are always associated with the disease. In the Netherlands, the disease is caused by the following three types of virus particles, either alone or in combination: isometric particles, diameter 25 and $34 \mathrm{~nm}$, respectively, and elongated particles with rounded ends, size $19 \times 50 \mathrm{~nm}$ (Dieleman-van Zaayen and Temmink, 1968). Recently, one particle type has been observed in ultrathin sections of diseased mycelium (Dieleman-van Zaayen and Igesz, 1969). 
The disease is spread by viable mycelium (Gandy, 1960) and by spores from diseased mushrooms (Schisler et al., 1967; Dieleman-van Zaayen, 1968).

\section{Mushroom growing in the Netherlands}

Mushrooms are grown on compost of horse manure and straw, which was subjected to outdoor composting for two weeks. After a mushroom growing room is filled with about $100 \mathrm{~kg} /{ }^{2}$ compost, the compost is pasteurized (up to $60^{\circ} \mathrm{C}$ ) for about 10 days. Cooling to $25^{\circ} \mathrm{C}$ is followed by spawning (spawn is mushroom mycelium grown on sterilized grains). After two weeks of mycelial growth in the compost at $25^{\circ} \mathrm{C}$, a casing layer of soil $(3-4 \mathrm{~cm})$ is added. The temperature is then slowly reduced to $15^{\circ} \mathrm{C}$ and after three weeks the first mushrooms can be harvested. These appear in flushes (weekly peaks). For five to six weeks the mushrooms are picked. The crop is then finished, the growing room emptied and after some days refilled with fresh compost. One crop takes 12 to 13 weeks.

\section{The problem}

Until recently, mushroom growers were advised to cook out the growing rooms at the end of a crop for at least $24 \mathrm{~h}$ at $70^{\circ} \mathrm{C}$ to destroy all the mycelium and spores; in case of virus disease they were advised to repeat this treatment after the room had been emptied. Such a prolonged heat treatment, however, is very detrimental to mushroom houses. Besides, it is highly questionable whether the mycelium, grown into the wood of trays and shelves, will be killed (Spradling Chidester, 1939). If not destroyed it will anastomose with mycelium of the following crop and may thus cause early virus infection and severe damage (Last et al., 1967; Dieleman-van Zaayen, 1970).

This problem has recently been solved by the application, after every crop, of wood preservatives based on sodium pentachlorophenate. Cooking-out can then be reduced to $12 \mathrm{~h}$ at $70^{\circ} \mathrm{C}$, before emptying the room, merely to kill mushroom mycelium and harmful organisms in the compost which is afterwards used for other horticultural purposes.

The growing houses, however, still suffer from this 12 -h heat treatment, and steam installations are not everywhere available. In England, good results were claimed with methyl bromide in the gas phase, either during the final stages of compost preparation to eradicate pests and harmful micro-organisms (Hayes and Randle, 1968), or as a substitute for cooking-out with live steam at the end of a crop to disinfect growing houses and to kill mushroom mycelium, other micro-organisms and pests in the compost (Hussey et al., 1962; Flegg, 1968).

According to unpublished work by Dr F. T. Last a CTP (Concentration Time Product) of $600 \mathrm{~g} \cdot \mathrm{h}^{-1} \cdot \mathrm{m}^{-3}$ would kill virus-infected mushroom mycelium (Flegg, 1968).

Hayes (1969) described a number of experiments on methyl bromide fumigation of spores, fruiting bodies and mycelium of cultivated mushroom and of mycelium and fruitbody tissues of Verticillium malthousei Ware, a pathogenic fungus in mushroom culture. With respect to virus disease, he stressed the necessity to kill viable mushroom spores and mycelial fragments. His results suggested, that methyl bromide fumigation can, with advantage, replace the traditional cooking-out with steam. However he tested only healthy mushroom tissue, mycelium and spores.

From these data it was decided worthwhile to see whether methyl bromide, although very poisonous, could be used in the Dutch mushroom growing industry, particularly to control the virus disease. A second possible application was the central disinfection of picking boxes or baskets. These baskets, used a number of times by different 
growers, had earlier been shown to contribute in spreading the virus disease all over the country (Dieleman-van Zaayen and Van Tilburg, 1968, 1969).

A comparison was made with formaldehyde vapour, which is easier to handle and less poisonous. It is used in the Netherlands as a general disinfectant for control of the mushroom virus disease.

Co-operation between the Mushroom Experiment Station, the Plant Protection Service and the Institute of Phytopathological Research allowed a comprehensive experiment.

\section{Material and methods}

The trials were done in an experimental fumigation chamber of the Plant Protection Service at Wageningen. It is made of iron, with oil-painted walls, of $3 \mathrm{~m}^{3}$ capacity and with a gas circulation system charging $120 \mathrm{~m}^{3} / \mathrm{h}$. With a heating unit a temperature of $20^{\circ} \mathrm{C}$ was maintained throughout the experiments. Liquid methyl bromide stored under pressure in a cylinder was led into a glass measure whence by opening a tap it passed through a volatilizer via the circulation system into the fumigation chamber. The fan in the circulation system was continuously operated to maintain a homogeneous gas/air mixture.

Several objects (indicated 1-6) were successively subjected to three methyl bromide fumigation trials (Experiments I-III). Experiment IV concerns a formaldehyde treatment.

The fumigated objects will be discussed in the following sequence:

1. Wooden trays of $57 \times 110 \times 15 \mathrm{~cm}$, in which virus-diseased mushrooms had been grown commercially. At the end of the crop, the trays were emptied but not disinfected (Exp. I).

2. Compost, permeated with virus-diseased mushroom mycelium, obtained from a contaminated mushroom farm (Exp. I).

3. Spores from virus-diseased and healthy mushrooms collected on filter paper (Exp. II).

4. Various virus-diseased and healthy mycelial isolates on $2 \%$ Biomals agar in test tubes (Exp. II and III).

5. Self-prepared spawn from various virus-diseased and one healthy mycelial isolates in glass tubes or flasks (Exp. II and III).

6. Corn weevils, to ascertain whether methyl bromide can penetrate glass tubes sealed with filter paper instead of cottonwool plugs, as employed in fumigation of objects 4 and 5 (Exp. II).

Each treatment included non-fumigated controls.

Experiment I was at atmospheric pressure; immediately before the methyl bromide dosages of Experiments II and III were applied, the absolute pressure in the chamber was reduced by a vacuum pump to about $70 \mathrm{~cm}$ of mercury, to stimulate penetration of the gas into the test tubes with mycelium. After dosage of methyl bromide the atmospheric pressure in the chamber was restored by allowing air to enter through a small aperture.

During Experiment I (trays and compost) the concentration of the 'free' methyl bromide in the chamber was regularly measured by means of a thermal conductivity meter ('Gow-Mac Gasmaster'), that previously had been stamped and verified for this purpose, using data of van de Pol and Mathôt (1961). The CTP's were calculated by 
multiplication of the measured concentration of 'free' methyl bromide (in $\mathrm{g} / \mathrm{m}^{3}$ ) and the exposure time (in $\mathrm{h}$ ), according to the EPPO-report on fumigation standards (1961).

In Experiments II (mushroom mycelium on agar, spawn, and spores on filter paper) and III (mycelium and spawn) the initial dosages, necessary for a given CTP, were calculated. Taken into account was a certain loss by sorption, which was gathered from earlier experimentation (Van de Pol and Mathôt, 1961). In fumigation of mycelium, spawn and spores, losses due to sorption were considerably smaller than in fumigation of wooden trays and compost (about 6 and $24 \%$ respectively).

Methyl bromide fumigation was always carried out for about $24(21-27) \mathrm{h}$. After every treatment the fumigation chamber was ventilated for about $30 \mathrm{~min}$.

In the same fumigation chamber at atmospheric pressure a comparison was made with the effect of formaldehyde vapour on virus-diseased and healthy mushroom mycelium and on spores from diseased mushrooms (Experiment IV).

Further technical details will be given when describing the trials.

\section{Experiments and results}

\section{Fumigation of contaminated trays (Exp. I)}

The trays, obtained from a contaminated farm, had previously contained a crop with severe symptoms of virus disease. Before and immediately after fumigation the nine trays to be examined were enveloped separately in plastic to prevent mutual contamination, and were then stored at $4^{\circ} \mathrm{C}$. After they had been restored to the mushroom farm concerned, the trays were filled with compost of horse manure and straw. After 12 days of pasteurization the compost was spawned with commercial mushroom spawn (Sinden). For some weeks there was mycelial growth in the compost and then a casing layer of soil was added.

About three weeks later the first mushrooms were harvested. From the same farm 159 similar, non-disinfected and non-fumigated trays were treated with a $2 \%$ solution of the wood preservative sodium pentachlorophenate (SPCP), with sodium carbonate as a wetting agent. Ten other trays served as controls.

Table 1. Visual judgment of crop on fumigated (Exp. I), untreated and SPCP-treated trays, and detection of virus particles in the mushrooms.

\begin{tabular}{|c|c|c|c|}
\hline $\begin{array}{l}\text { Number } \\
\text { of trays }\end{array}$ & Treatment & $\begin{array}{l}\text { Estimated } \\
\text { number of } \\
\text { 'healthy' trays }\end{array}$ & Virus particles ${ }^{1}$ \\
\hline \multirow[t]{2}{*}{10} & - (control) & 4 & Many 25,34 , and $19 \times 50 \mathrm{~nm}$ \\
\hline & $\begin{array}{l}\text { Methyl } \\
\text { bromide: }\end{array}$ & & \\
\hline 3 & $612 \mathrm{CTP}$ & 2 & Relatively few $25,34,19 \times 50 \mathrm{~nm}$ (Fig. 1) \\
\hline 3 & 712 CTP & 1 & No particles observed \\
\hline 3 & $801 \mathrm{CTP}$ & 0 & Relatively few $25,34,19 \times 50 \mathrm{~nm}$ \\
\hline 159 & SPCP $2 \%$ & $136^{2}$ & No particles observed \\
\hline
\end{tabular}

1 The figures in italics indicate the particle type(s) prevailing in that virus preparation.

2 This number could have been higher, but a number of the trays were infected by Verticillium sp. 


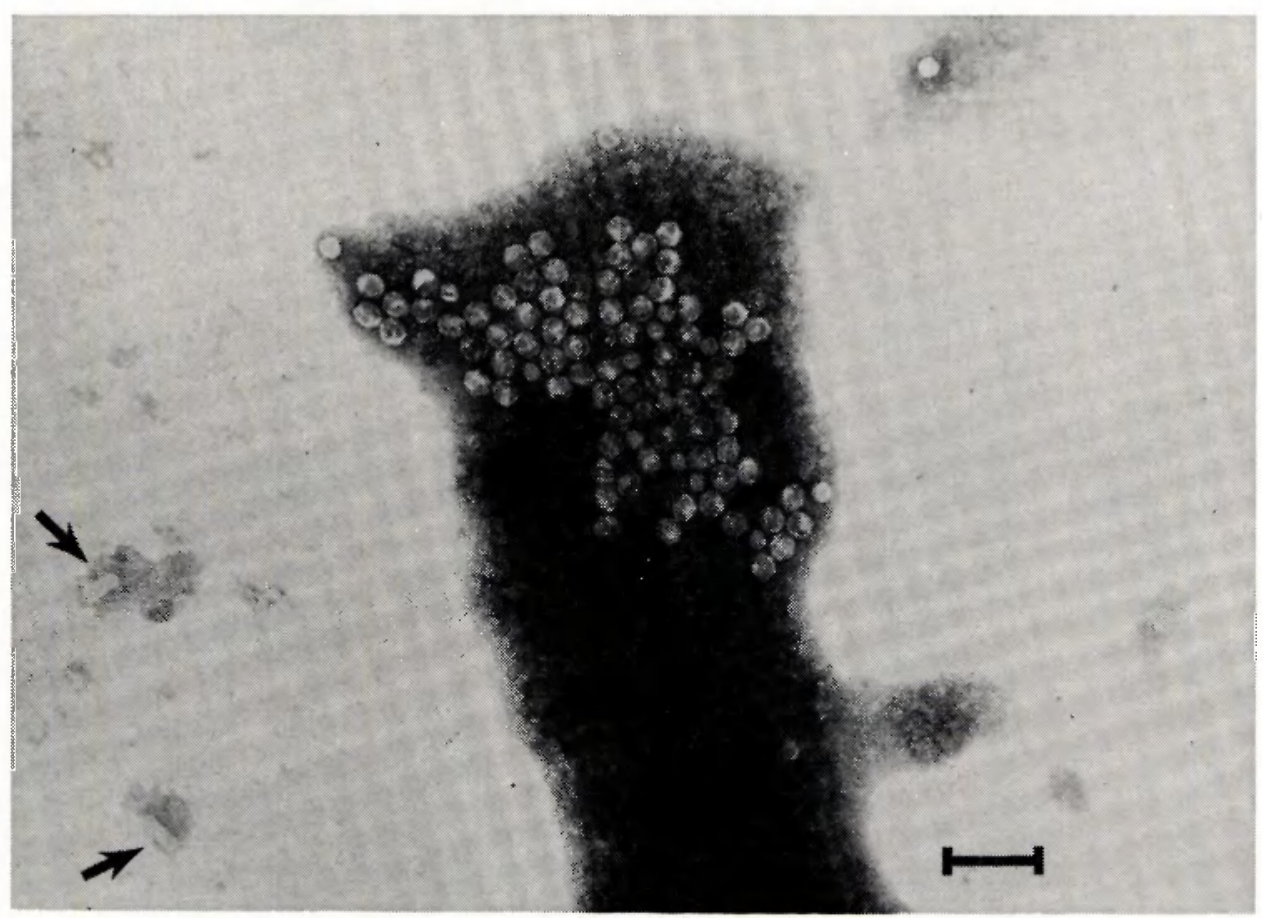

Fig. 1. Electron micrograph of virus particles of 25,34 and $19 \times 50$ (arrows) $\mathrm{nm}$, detected in mushrooms grown on trays, fumigated with 612 CTP methyl bromide. Marker indicates $100 \mathrm{~nm}$.

The mushrooms were visually judged for symptoms when sampled and then diagnosed for virus particles according to a special method developed by Dieleman - van Zaayen and Temmink (1968). The results are given in Table 1 and Fig. 1.

The effect of SPCP is evident. Treatment with $4 \%$ SPCP would most probably have been even more efficient.

As for methyl bromide, even a CTP of 800 seemed to be insufficient for disinfection, even though the trays were not only fumigated, but also peak-heated. The compost on this farm, however, may not have reached $60^{\circ} \mathrm{C}$ during peak-heating.

It is not certain whether methyl bromide is inadequate because of insufficient fungicidal action or because of insufficient penetration of the gas into the wood.

\section{Fumigation of compost permeated with mushroom mycelium (Exp. I)}

A. Portions $(70 \mathrm{~g})$ of fumigated and untreated compost (stored at $4^{\circ} \mathrm{C}$ ) were put into a corner of steam-sterilized $30 \times 30 \times 25 \mathrm{~cm}$ trays, which were filled with a layer (some $20 \mathrm{~cm}$ ) of compost of horse manure and straw and spawned with $35 \mathrm{~g}$ commercial spawn (Somycel 32) per tray. Inoculation with treated or untreated compost was done seven days after spawning.

B. The above procedure (A) was repeated after some months with the same compost and mycelium, stored at $10^{\circ} \mathrm{C}$. This time inoculation with portions of $80 \mathrm{~g}$ compost was done 11 days after spawning. Both experiments were done in duplicate. The yields (in three weeks of picking) and results of testing for virus particles of two trays were 
Table 2. Yields of and virus particles in crop on small trays, inoculated with fumigated (Exp. 1) compost (averages of two trays).

\begin{tabular}{|c|c|c|c|c|}
\hline \multirow[t]{2}{*}{ Treatment } & \multicolumn{2}{|l|}{ A } & \multicolumn{2}{|l|}{ B } \\
\hline & Yields (g) & Virus particles ${ }^{1}$ & Yields (g) & Virus particles ${ }^{1}$ \\
\hline$-\underset{\text { control) }}{\text { (inoculated }}$ & 40 & Many 25 and $34 \mathrm{~nm}$ & 40 & Many 25,34 and $19 \times 50 \mathrm{~nm}$ \\
\hline 299 CTP & 193 & Relatively many $25,34,19 \times 50 \mathrm{~nm}$ & 63 & Many 25 and $34 \mathrm{~nm}$ \\
\hline 400 СТР & 45 & Rel, few $25 \mathrm{~nm}$ & 180 & Few $25 \mathrm{~nm}$ \\
\hline 499 CTP & 78 & Rel. few 25 and $34 \mathrm{~nm}$ & 350 & Few 25 and $34 \mathrm{~nm}$ \\
\hline 612 CTP & 85 & Rel. many $25,34,19 \times 50 \mathrm{~mm}$ (Fig. 4) & 540 & Few 25 and $34 \mathrm{~nm}$ \\
\hline 712 СТP & 105 & Rel. many $25 \mathrm{~nm}$ & 495 & Rel. many $25,34,19 \times 50 \mathrm{~nm}$ \\
\hline 801 CTP & 190 & Many $25 \mathrm{~nm}$ & 350 & Rel. few $25,34,19 \times 50 \mathrm{~nm}$ (Fig. 5) \\
\hline
\end{tabular}

The figures in italics indicate the particle type(s) prevailing in that virus preparation.

averaged. Mushrooms growing on trays were tested for virus at least twice. The results are given in Table 2. These experiments were carried out at the Mushroom Experiment Station at Horst (L).

Yields of B were higher than those of A because of more favourable climatic conditions in the isolated virus growing room at that time. Yields were variable, however. Yet the higher CTP's of methyl bromide led to better yields than the lower CTP's. Obviously even a CTP of 800 cannot free compost from virus, that is kill the virus-

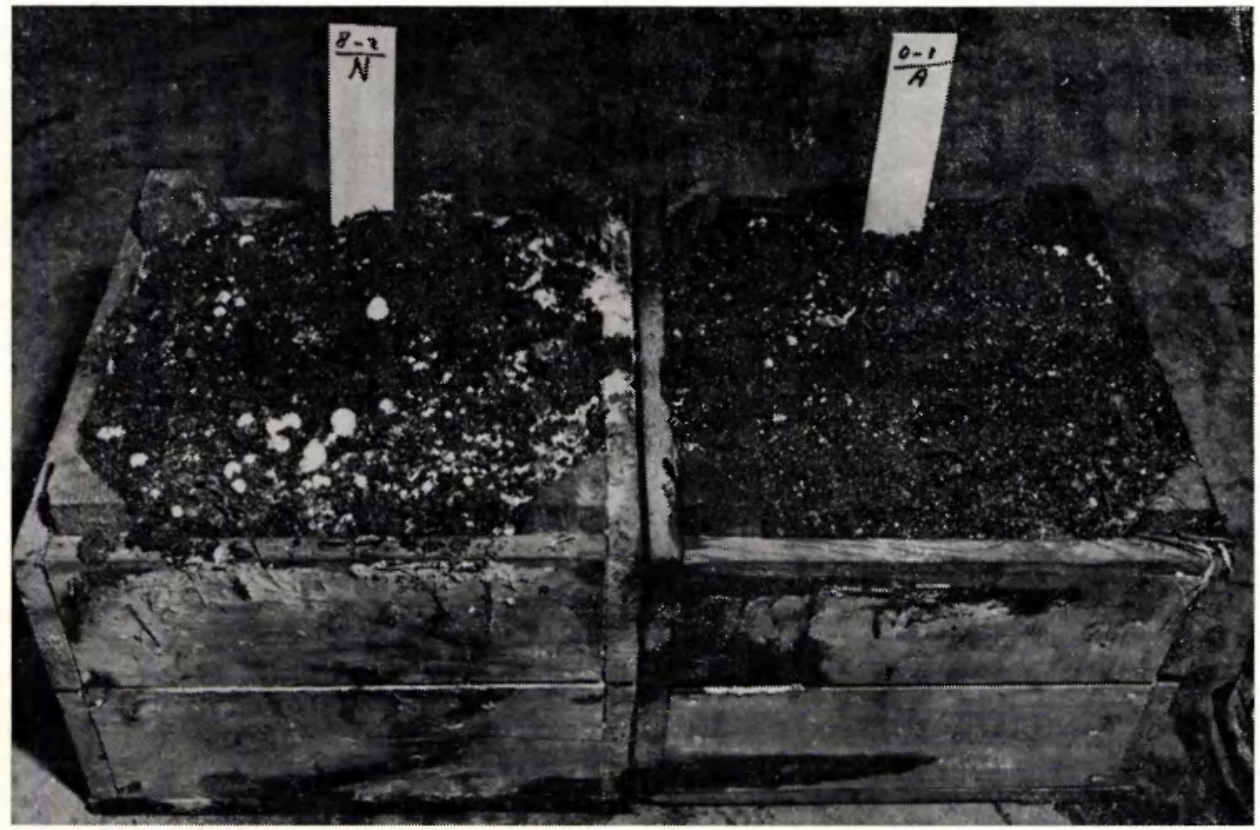

Fig. 2. Trays inoculated with untreated, infected compost (right) and with 800 CTP-fumigated compost (left). The right tray yielded a virus-diseased culture; the tray on the left seemed healthy. 


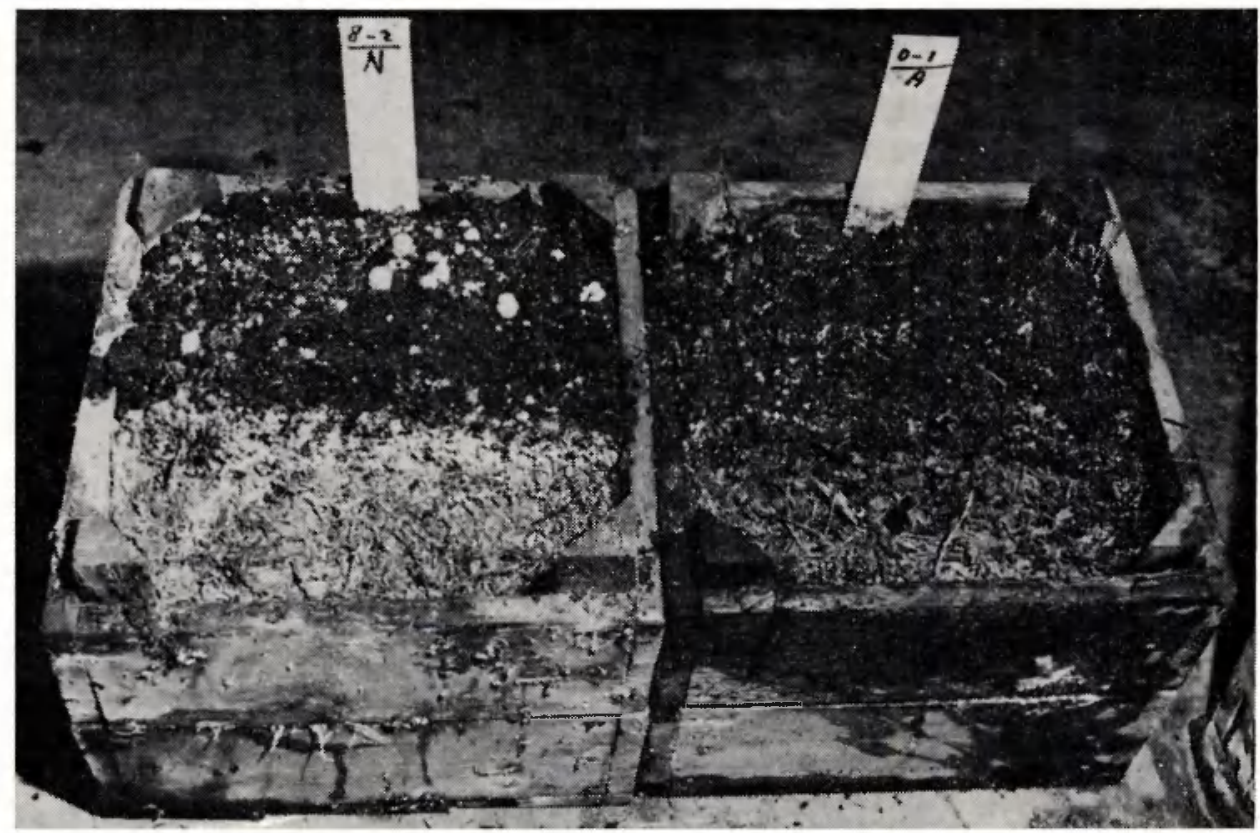

Fig. 3. Section through compost (bclow) and casing soil from the trays represented in Fig. 2. Right tray: no mycelium is left in the casing soil.

infected mycelium in the compost. The CTP of 400 always showed a remarkably good result as for the amount of virus particles. However, this part of the fumigated mycelium may have been less diseased than the other compost samples.

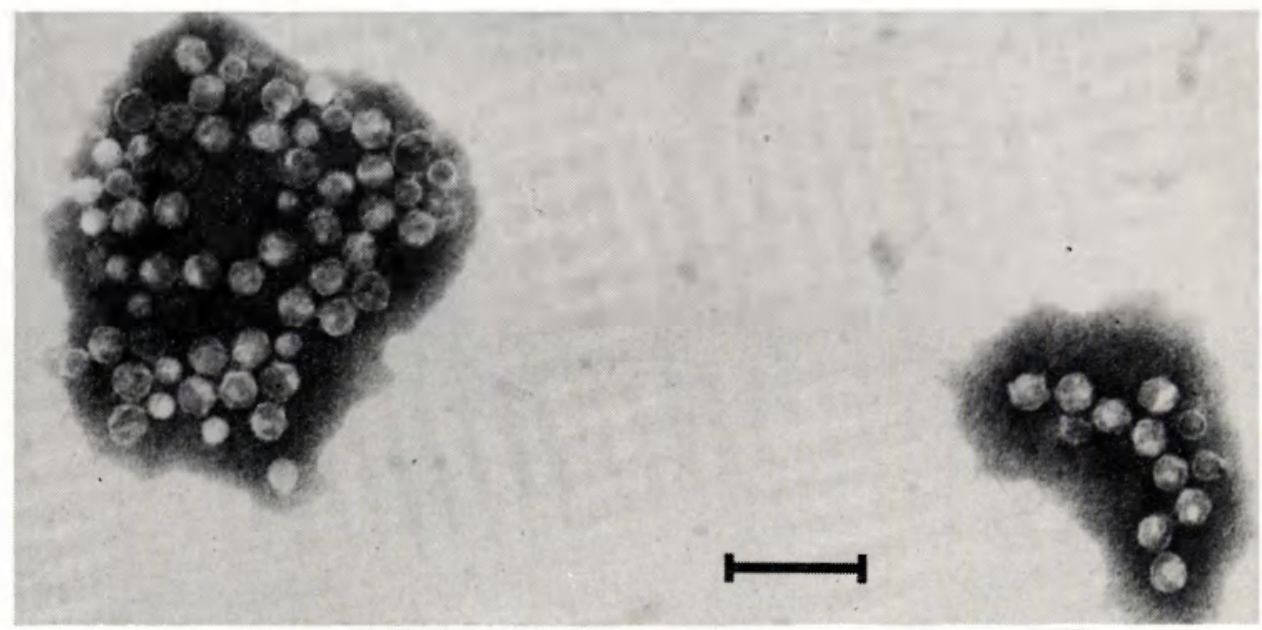

Fig. 4. Electron micrograph of virus particles of 25 and $34 \mathrm{~nm}$, detected in mushrooms from trays, inoculated with 612 CTP-fumigated compost (A in Table 2). Marker indicates $100 \mathrm{~nm}$. 


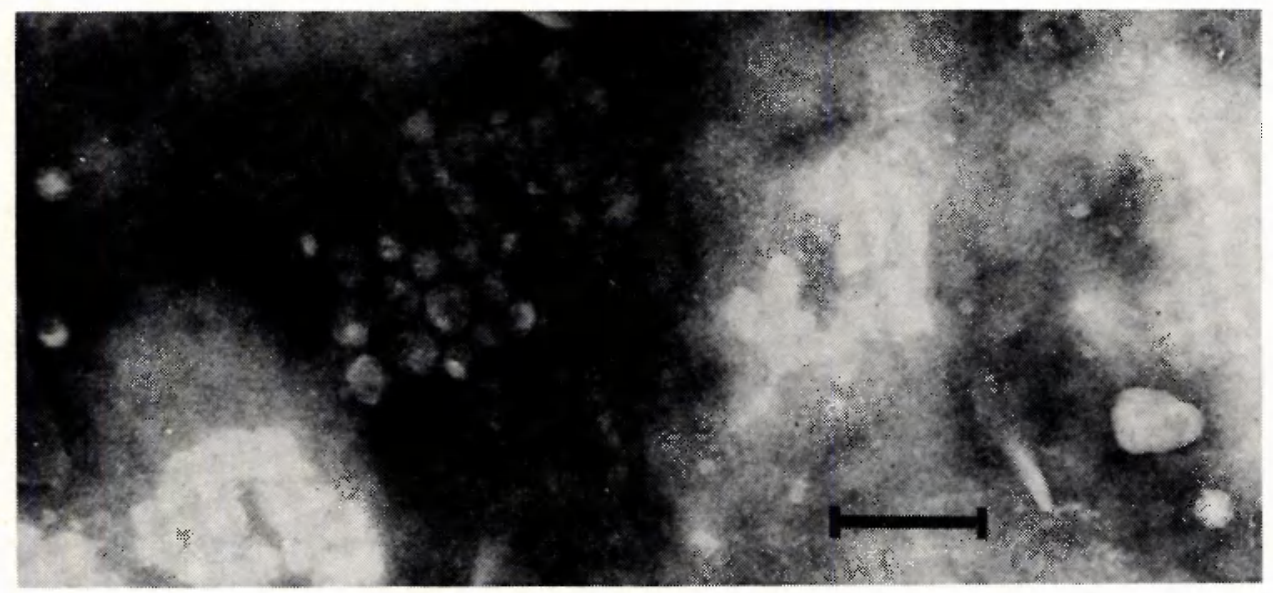

Fig. 5. Electron micrograph of virus particles, detected in mushrooms from trays, inoculated with 801 CTP-fumigated compost ( $\mathrm{B}$ in Table 2). Marker indicates $100 \mathrm{~nm}$.

Fig. 2 (right) shows a tray, inoculated with untreated compost and virus-diseased mycelium, and a tray (left) inoculated with methyl bromide-fumigated compost and virus-diseased mycelium ( $800 \mathrm{CTP}$ ). The right tray yielded a virus-diseased culture: the few mushrooms that developed contained many virus particles. The tray on the left seemed healthy. Fig. 3 shows a section through compost (below) and casing soil from the same trays (right: untreated; left: 800 CTP methyl bromide). In the casing soil of the tray, inoculated with untreated compost, no mycelium is left, and this is characteristic of the virus disease. In the tray, inoculated with 800 CTP-fumigated compost, there is mycelium left but the mushrooms produced contained many virus particles of $25 \mathrm{~nm}$ (Table 2A). See also Fig. 4 and 5.

Uninoculated control trays yielded a healthy crop.

3 Fumigation of spores from virus-diseased and healthy mushrooms (Exp. II)

Spores were collected by placing virus-diseased or healthy mushrooms under a beaker on filter paper. The mushrooms had first been surface-sterilized by a $0.2 \%$ solution of mercuric chloride $\left(\mathrm{HgCl}_{2}\right)$. The spore prints were stored in a Petri dish until

Table 3. Mycelial growth in $\mathrm{mm}$ on agar after germination of fumigated spores from virus-diseased and healthy mushrooms (Exp. II).

\begin{tabular}{|c|c|c|c|c|c|c|}
\hline \multirow[t]{3}{*}{ Treatment } & \multicolumn{6}{|c|}{ Mycelial growth (mm) } \\
\hline & \multicolumn{3}{|c|}{ ‘diseased' spores } & \multicolumn{3}{|c|}{ 'healthy' spores } \\
\hline & Tube 1 & Tube 2 & Tube 3 & Tube 1 & Tube 2 & Tube 3 \\
\hline- (control) & 65 & 46 & 61 & 71 & 97 & \pm \\
\hline 370 CTP & 3 & 0 & \pm & 42 & 45 & \pm \\
\hline 561 CTP & 0 & 0 & 0 & 0 & 0 & \pm \\
\hline 741 СТP & 0 & 0 & 0 & 0 & 0 & \pm \\
\hline
\end{tabular}

$\pm=$ contaminated $; 0=$ no growth, no germination. 
fumigation. Just before fumigation the lid of the Petri dish was replaced by a sheet of filter paper, which was attached to the bottom of the dish. The filter paper was used because it was supposed to establish better contact with methyl bromide during treatment. Immediately after fumigation the lid was returned. Some spores were then scraped from the fumigated spore prints and transferred to a nutrient medium ( $2 \%$ Biomals agar) in three test tubes per treatment. Germination was determined after 25 days by measuring the mycelial growth in $\mathrm{mm}$ (Table 3 ).

Spores, and especially 'diseased' spores, were highly sensitive to methyl bromide fumigation. A relatively low dosage of 370 CTP retarded growth of mycelium from 'healthy' spores, and nearly killed 'deseased' spores.

Table 3 also shows that healthy mycelium grew faster than virus-diseased mycelium (see untreated spores). This is another characteristic of mushroom virus disease (Gandy, 1960).

\section{Fumigation of virus-diseased and healthy mycalium on agar (Exp. II and III)}

The mycelial isolates No 1, 28, 52 and 92 (with 97 in Exp. III) from our 'virus collection', and a healthy isolate No 37, all maintained on $2 \%$ Biomals agar, were fumigated. Some isolates were treated in duplicate, others in triplicate or in quintuplicate. This was done because of variation in growth rate and possibly in response to fumigation with methyl bromide. Just before fumigation, the cottonwool plugs on top of the test tubes were replaced by a cover of sterilized $\left(30\right.$ minutes at $\left.120^{\circ} \mathrm{C}\right)$ filter paper which was attached to the tubes by a piece of elastic. Immediately afterwards the

Table 4. Growth of fumigated virus-diseased and healthy mycelia in mm (Exp. II).

\begin{tabular}{|c|c|c|c|c|c|c|c|c|c|c|c|c|}
\hline \multirow[t]{3}{*}{ Treatment } & \multirow{3}{*}{1} & \multicolumn{11}{|c|}{ Growth of fumigated mycelia $(\mathrm{mm})$ from isolate No } \\
\hline & & \multicolumn{2}{|l|}{28} & \multicolumn{5}{|c|}{37 (healthy) } & \multirow[t]{2}{*}{52} & \multicolumn{3}{|l|}{92} \\
\hline & & I & II & $\mathbf{I}$ & II & III & IV & $\mathbf{V}$ & & I & II & III \\
\hline - (control) & 74 & 63 & 50 & 75 & 63 & 67 & 90 & 65 & 83 & 51 & 62 & 58 \\
\hline $370 \mathrm{CTP}$ & 82 & 50 & 39 & 70 & 56 & 67 & 83 & 62 & 36 & 28 & 0 & 49 \\
\hline 561 CTP & 0 & 41 & 40 & 0 & 0 & 0 & 0 & 0 & 62 & 0 & 0 & 0 \\
\hline 741 CTP & 0 & 0 & 0 & 0 & 0 & 0 & 0 & 0 & $13^{1}$ & 0 & 0 & 0 \\
\hline
\end{tabular}

1 Mycelium started to grow later on.

Table 5. Growth of fumigated virus-diseased and healthy mycelia in $\mathrm{mm}$ (Exp. III).

\begin{tabular}{|c|c|c|c|c|c|c|c|c|c|c|c|c|c|c|}
\hline \multirow[t]{3}{*}{ Treatment } & \multicolumn{14}{|c|}{ Growth of fumigated mycelia $(\mathrm{mm})$ from isolate No } \\
\hline & \multicolumn{2}{|l|}{1} & \multicolumn{2}{|l|}{28} & \multicolumn{2}{|c|}{$\begin{array}{l}37 \\
\text { (healthy) }\end{array}$} & \multicolumn{4}{|l|}{52} & \multicolumn{2}{|l|}{92} & \multicolumn{2}{|l|}{97} \\
\hline & $\mathbf{I}$ & II & I & II & I & II & I & II & III & IV & $\mathbf{I}$ & II & I & II \\
\hline- (control) & 52 & 61 & 63 & 55 & 58 & 62 & 58 & 55 & 52 & 47 & 64 & 67 & 33 & 56 \\
\hline 692 CTP & 32 & \pm & 32 & 33 & 0 & 32 & 28 & 25 & \pm & 42 & 41 & 56 & 29 & 39 \\
\hline 899 CTP & 0 & 0 & 0 & 0 & 0 & 0 & 0 & 0 & 0 & 0 & 0 & 0 & 0 & 0 \\
\hline 1103 CTP & 0 & 0 & 0 & 0 & 0 & 0 & 0 & 0 & 0 & 0 & 0 & 0 & 0 & 0 \\
\hline
\end{tabular}


cottonwool plugs were restored. Pieces of agar with mycelium were then transferred to test tubes with fresh Biomals agar. After 25 days the growth of the mycelium was measured in mm (22 days for Exp. II, 741 CTP).

The results given in Tables 4 and 5 prove, that about 600 CTP methyl bromide does not kill mycelium on agar, though growth is reduced. Some isolates, for instance number 37 (healthy), are apparently more sensitive to methyl bromide than others. A certain difference in response to fumigation can be seen between Experiments II and III, 561 and 692 CTP, respectively: though the dosage in Exp. III was higher than in Exp. II, more isolates survived the treatment in Exp. III. The age of the mycelium might be of influence.

\section{Fumigation of spawn (Exp. II and III)}

Spawn was prepared in the following way. Sorghum grains were boiled with water for $5 \mathrm{~min}$. Then $2.33 \mathrm{~g}$ gypsum and $0.66 \mathrm{~g}$ calcium carbonate per $100 \mathrm{~g}$ sorghum were added and thoroughly mixed. The mixture was sterilized for $2 \mathrm{~h}$ at $120^{\circ} \mathrm{C}$. After cooling down, pieces of agar with mycelium were transferred to the flasks or tubes with grains. After $1-2$ weeks the grains were permeated with mycelium.

Spawn from various isolates was fumigated in:

Exp. II : wide glass tubes, diameter $3.0 \mathrm{~cm}$;

Exp. III: wide glass tubes, diameter $3.0 \mathrm{~cm} ; 300-\mathrm{ml}$ flasks with a wide neck.

Again the cottonwool plugs were replaced by sterilized filter paper just before fumigation. After fumigation some spawn grains from the bottom of tube or flask were transferred to Biomals agar. Mycelial growth was measured after 25 days.

Various mycelia (spawn), among which one healthy (No 37b), were subjected to different fumigation treatments without duplicates $(a$ and $b$ indicate different strains of a mycelial isolate). The results are given in Tables 6 and 7 and those of Experiment III in Fig. 6. The excellent growth of number 112a is clearly visible, despite a dose

Table 6. Growth of mycelium (mm) from fumigated spawn (Exp. II).

\begin{tabular}{|c|c|c|c|c|c|c|c|c|c|c|}
\hline \multirow[t]{2}{*}{ Treatment } & \multicolumn{10}{|c|}{ Growth of mycelium ( $\mathrm{mm}$ ) from isolate No } \\
\hline & $\begin{array}{l}37 \mathrm{~b} \\
\text { (healthy) }\end{array}$ & $112 \mathrm{a}$ & $7 \mathrm{a}$ & $7 \mathrm{~b}$ & $69 a$ & $69 b$ & $40 \mathrm{a}$ & $40 \mathrm{~b}$ & $94 a$ & $94 b$ \\
\hline - (control) & 60 & 47 & & & & & & & & \\
\hline 370 СТP & & & 13 & 20.5 & & & & & & \\
\hline 561 CTP & & & & & \pm & \pm & & & & \\
\hline 741 CTP & & & & & & & 23 & 26 & 30 & 0 \\
\hline
\end{tabular}

Table 7. Growth of mycelium (mm) from fumigated spawn (Exp. III).

\begin{tabular}{|c|c|c|c|c|c|c|c|c|c|c|}
\hline \multirow[t]{2}{*}{ Treatment } & \multicolumn{10}{|c|}{ Growth of mycelium (mm) from isolate No } \\
\hline & $92 b$ & $94 b$ & $97 \mathrm{a}$ & $97 b$ & $40 \mathrm{a}$ & $40 \mathrm{~b}$ & $112 \mathrm{a}$ & $112 b$ & $92 \mathrm{a}^{1}$ & $94 a^{1}$ \\
\hline - (control) & 49 & 70.5 & & & & & & & 30.5 & 68.5 \\
\hline 692 CTP & & & 29 & 54.5 & & & & & 28.5 & 34 \\
\hline 899 CTP & & & & & 19 & 0 & & & 17 & 0 \\
\hline $1103 \mathrm{CTP}$ & & & & & & & + & 0 & + & 0 \\
\hline
\end{tabular}

1 Flasks; + Mycelium started to grow later on. 


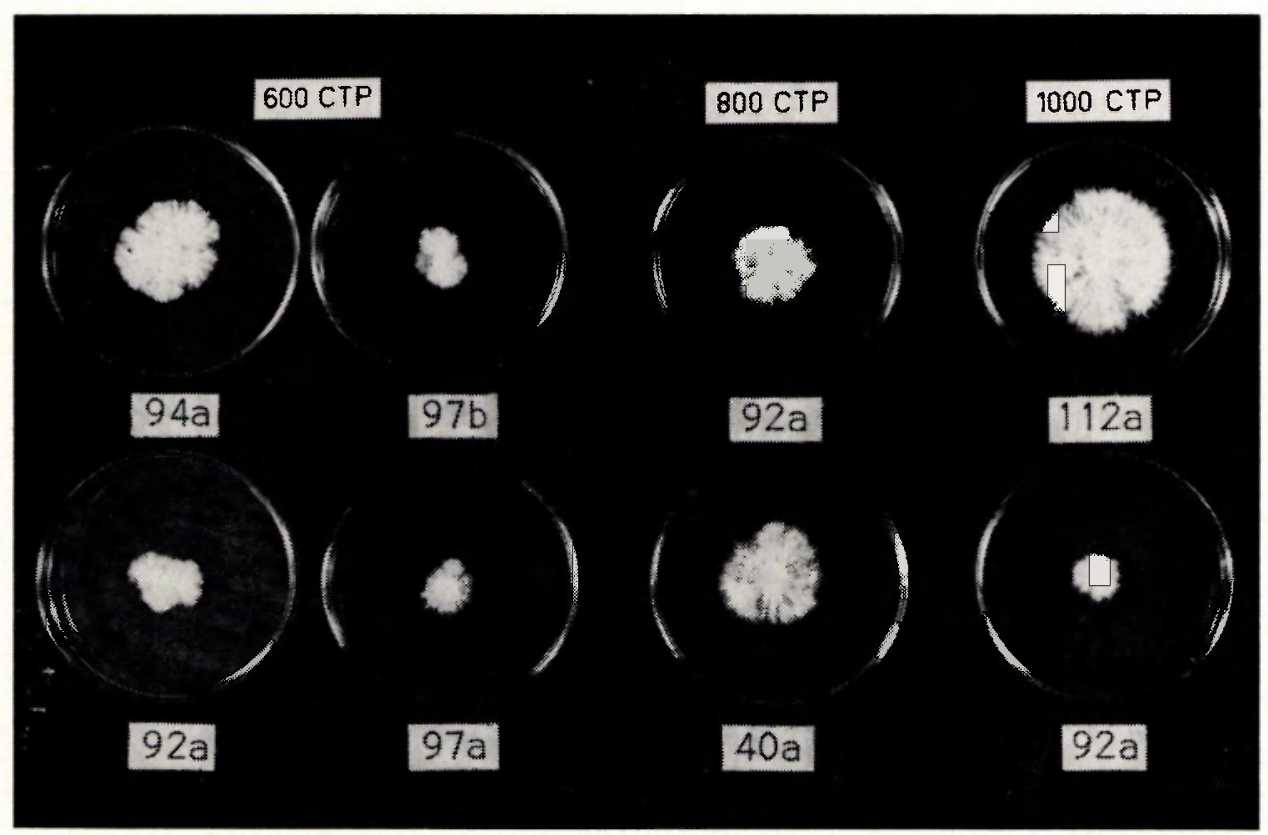

Fig. 6. Mycelium from fumigated spawn. CTP's are rounded off downwards. For explanation, see text.

of over 1000 CTP. It is obvious from these results that 600 CTP is not sufficient to kill mycelium in the form of spawn. Even a CTP of 1103 cannot destroy all types of mycelia on grains of sorghum.

6 Fumigation of corn weevils (Exp. II)

During Experiment II, five tubes each with 50 corn weevils, were added to every treatment except that with 741 CTP. Each tube had a diameter of $3.0 \mathrm{~cm}$ and was sealed with filter paper. When counted immediately after fumigation, all $5 \times 50$ controls were alive, but none of the fumigated corn weevils $(5 \times 50$ at $370 \mathrm{CTP}, 5 \times 50$ at 561 CTP) survived. This indicates penetration of the gas through the cover of filter paper into the tubes.

The effect of formaldehyde vapour on spores and mycelium (Exp. IV)

For comparison various virus-diseased (No 40, 52, 92 and 112) and healthy (a 'Sinden' isolate) mycelia and spores from virus-diseased mushrooms were exposed to formaldehyde vapour in the fumigation chamber. Each isolate, growing on $2 \%$ Biomals agar in test tubes, was treated in duplicate. Cottonwool plugs were replaced by sterilized filter paper as described before. After formaldehyde fumigation, pieces of agar with mycelium were transferred to tubes with fresh agar. Growth of the mycelium was determined after 24 days. For each treatment one spore print was fumigated in a Petri dish, the lid of which had been replaced by a cover of filter paper. After fumigation some spores were transferred to 5 Petri dishes with agar per treatment. Fumigation took place for $1,2,3$ and $24 \mathrm{~h}$. Formaldehyde vapour was produced inside the fumigation chamber by mixing $52.5 \mathrm{~g}$ potassium permanganate with $105 \mathrm{ml}$ 
Table 8. Influence of formaldehyde fumigation on virus-diseased and healthy mycelium and on germination of spores from virus-diseased mushrooms (Exp. IV).

\begin{tabular}{|c|c|c|c|c|c|c|c|c|c|c|c|}
\hline \multirow{3}{*}{$\begin{array}{l}\text { Treatment } \\
\text { exposure } \\
\text { time (h) }\end{array}$} & \multicolumn{10}{|c|}{ Isolate No } & \multirow{3}{*}{$\begin{array}{l}\text { Spores (5 } \\
\text { repetitions } \\
\text { per treatment) }\end{array}$} \\
\hline & \multicolumn{2}{|l|}{40} & \multicolumn{2}{|l|}{52} & \multicolumn{2}{|l|}{92} & \multicolumn{2}{|c|}{112} & \multicolumn{2}{|c|}{$\begin{array}{l}\text { Sinden } \\
\text { (healthy) }\end{array}$} & \\
\hline & 1 & II & 1 & II & I & II & I & II & I & II & \\
\hline$\ldots$ (control) & + & + & + & + & + & + & + & + & + & + & + \\
\hline 1 & + & + & + & + & + & + & + & + & + & - & - \\
\hline 2 & + & + & + & + & + & + & + & + & + & + & - \\
\hline 3 & + & + & + & + & + & - & + & + & + & - & - \\
\hline 24 & - & - & - & - & - & - & - & - & 一 & - & - \\
\hline
\end{tabular}

+ Growth of mycelium; germination; - No growth; no germination.

commercial formaldehyde $36 \%$, and immediately afterwards the chamber door was closed. During treatments the inside temperature was kept at $25^{\circ} \mathrm{C}$. After each treatment the chamber was thoroughly ventilated for at least $30 \mathrm{~min}$. During this experiment the gassing method made it impossible to reduce the pressure to $70 \mathrm{~cm}$ of mercury, as in the methyl bromide experiments II and III.

Table 8 shows the results. This time the growth of the mycelium was not measured because treated mycelia, which started to grow, developed quite normally compared with untreated.

The sensitivity of spores was again demonstrated. Spores were already destroyed after one hour in formaldehyde vapour, whereas most mycelia still grew after a treatment for three hours.

However $24 \mathrm{~h}$ of formaldehyde vapour in the indicated concentration was sufficient to kill both spores and mycelium. Even a shorter period may do, but this was not investigated.

\section{Discussion}

The results prove that methyl bromide is an inadequate after-crop sterilant to control the virus disease of cultivated mushrooms, except for destruction of mushroom spores. The results with spores correspond to those obtained by Hayes (1969). Mushroom spores, however, can be destroyed in a much easier and much less dangerous way, either by heat treatment for one hour at $70^{\circ} \mathrm{C}$ or with a certain dosage of formaldehyde vapour for one hour (Experiment IV). Spores from virus-diseased mushrooms seemed more sensitive to methyl bromide fumigation than spores from healthy mushrooms. This might be due to a reduction of spore wall thickness by infection, as already supposed by Schisler et al. (1967).

The results of fumigating mycelium and spawn were variable. Grain spawn makes the mycelia even more resistant. Hayes (1969) also reported variable results, which he attributed to an ineffective concentration of methyl bromide or too low temperature during fumigation. Hayes's trials, restricted to healthy mushroom tissue, were done in polythene chambers and in growing houses of several commercial mushroom farms, whereas our experiments were carried out in a gastight experimental fumigation chamber with adjustable equipment. In Hayes's opinion, a minimum air temperature of $67^{\circ} \mathrm{F}\left(=19.5^{\circ} \mathrm{C}\right)$ should be maintained during fumigation. This was so in all our 
experiments. Nevertheless, fumigation did not kill all mycelia at about 600 CTP (Tables 4 and 5) and did not completely destroy spawn at about 800 CTP (Tables 6 and 7). This implies that fumigation of mushroom houses would demand extremely high CTP's of methyl bromide to kill all virus-diseased mycelium.

Our experiments, partly practical (trays and compost), partly fundamental (mycelium, spawn, spores in tubes or Petri dishes), were perhaps more sensitive than Hayes's trials, since ours concerned virus-diseased mycelium. For instance, with trays destruction of healthy mycelium is difficult to demonstrate, but if virus-diseased mycelium grown into the wood of a tray has not been destroyed during fumigation, it will anastomose with healthy mycelium of the next crop and thus transmit the virus. If virus is demonstrated in mushrooms of this new crop, the tray obviously was not effectively disinfected.

Since no other reliable test for virus is available so far, the virus-diseased nature of a mushroom crop can only be established with an electron microscope: see for instance Fig. 2 and 3 (fumigated compost, $800 \mathrm{CTP}$ ). In seemingly healthy crops the electron microscope revealed virus particles (Table $2 \mathrm{~A}$ ).

Some reports on application of methyl bromide in England are promising. There, however, a good deal of the mushrooms are picked as 'open' mushrooms, so that the amount of spores in the mushroom growing areas must be tremendous. For example, a mushroom with a cap $8 \mathrm{~cm}$ diameter can produce 1,300 million spores (Sarazin, 1955).

Any treatment affecting spores will cause a reduction of virus disease. A less dangerous and equally effective treatment could have been considered, however. In November 1968 hygienic measures to prevent and control mushroom virus disease, based on our research, were advocated among mushroom growers in the Netherlands. An official inquiry over 1969 showed that the overall application of these measures considerably reduced the total crop loss in this country from $4.5 \%$ of the total production in 1967 to $1.3 \%$ in 1969 (Dieleman-van Zaayen and Van Tilburg, 1970).

Our experiments explicitly indicate that we cannot agree with Hayes's statement: 'Traditional cooking out with steam can, with advantage, be replaced by methyl bromide fumigation'. Moreover, the application of methyl bromide is dangerous. The danger is further increased since this poisonous gas is odorless in contrast to formaldehyde. Special equipment and continual control of the remaining gas after fumigation are very costly. The fumigation also cannot be carried out by the growers themselves. In the Netherlands it is impossible to apply the gas in mushroom farms, since most farm buildings are attached to the growers' private houses.

Crop disinfection with live steam $\left(12\right.$ hours at $70^{\circ} \mathrm{C}$, as we tested thoroughly) or, if no steam installation is available, with formaldehyde vapour $(24 \mathrm{~h} ; 71$ commercial formaldehyde $36 \%$ and $3.5 \mathrm{~kg} \mathrm{KMnO}_{4}$ per $200 \mathrm{~m}^{3}$; temperature $25^{\circ} \mathrm{C}$ ) must be preferred, though the disadvantages of steam (decline of cropping structures by heat stress) and of formaldehyde (poor penetration) are known. Consequently, the wood of trays and shelves has to be treated with the wood preservative sodium pentachlorophenate. This should also be applied after fumigation with methyl bromide.

For a (central) disinfection of picking boxes methyl bromide is unsuited.

\section{Acknowledgments}

The author wishes to express her sincere thanks to Ir P. H. van de Pol. Without his stimulating help and continuing interest these experiments could not have been per- 
formed. The skilful technical assistance of Miss W. Buter, who carried out the fumigations, and of P. J. van Tilburg, who did the mushroom growing and mycelial work, are gratefully acknowledged.

The electron micrographs are from the Laboratory of Virology, Agricultural University, Wageningen, and the photographs from the Institute of Phytopathological Research, Wageningen, the Netherlands.

\section{References}

Dieleman-van Zaayen, A., 1968. Sporen van zieke champignons verspreiden de afstervingsziekte. Champignoncultuur 12 (6): 192.

Dieleman-van Zaayen, A., 1969. A virus disease of cultivated mushrooms in the Netherlands. Mushroom Sci. $7: 213-220$.

Dieleman-van Zaayen, A., 1970. Means by which virus disease in cultivated mushrooms is spread, and methods to prevent and control it. MGA Bull. 244: 158-178.

Dieleman-van Zaayen, A. \& J. H. M. Temmink, 1968. A virus disease of cultivated mushrooms in the Netherlands. Neth. J. Pl. Path. 74: 48-51.

Dieleman-van Zaayen, A. \& P. J. van Tilburg, 1968. De rol van gebruikt fust bij de verspreiding van de afstervingsziekte. Champignoncultuur 12 (10): 336-337.

Dieleman-van Zaayen, A. \& P. J. van Tilburg, 1969. Gebruikt fust speelt nog steeds een rol bij de verspreiding van de afstervingsziekte. Champignoncultuur 13 (7): 264-265.

Dieleman-van Zaayen, A. \& O. Igesz, 1969. Intracellular appearance of mushroom virus. Virology 39 : $147-152$.

Dieleman-van Zaayen, A. \& P. J. van Tilburg, 1970. Afstervingsziekte: Enquête 1969. Champignoncultuur 14 (9): 293-294.

European and Mediterranean Plant Protection Organisation, 1961. Report of the working party on fumigation standards. Hemmerlé, Petit \& Cie, Paris.

Flegg, P. B., 1968. Methyl bromide and mushrooms. MGA Bull. 228: 582-584.

Gandy, D. G., 1960. 'Watery Stipe' of cultivated mushrooms. Nature, Lond. 185: 482-483.

Hayes, W. A., 1969. Methyl bromide as an after-crop sterilant. MGA Bull. 234: 240-243.

Hayes, W. A. \& P. E. Randle, 1968. The use of water soluble carbohydrates and methyl bromide in the preparation of mushroom composts. $M G A$ Bull. $218: 81-102$.

Hollings, M., 1962. Viruses associated with a die-back disease of cultivated mushrooms. Nature, Lond. 196: $962-965$.

Hussey, N. W., I. J. Wyatt \& J. J. Hesling, 1962. Entomology department report. Rep. Glasshouse Crops Res. Inst. 1961: 63-64.

Last, F. T., M. Hollings, \& O. M. Stone, 1967. Some effects of cultural treatments on virus diseases of cultivated mushroom, Agaricus bisports. Ann. appl. Biol. 59: 451-462.

Pol, P. H. van de \& A. M. Mathôt, 1961. The influence of commodity, packing material and the properties of the fumigation chamber on the concentration of methyl bromide $(\mathrm{MeBr})$ in the gas phase. Neth. J. agric. Sci. 9: 159-162.

Sarazin, A., 1955. The cultivated mushroom. Mushroom Growers' Association, London.

Schisler, L. C., J. W. Sinden \& E. M. Sigel, 1967. Etiology, symptomatology, and epidemiology of a virus disease of cultivated mushrooms. Phytopathology 57: 519-526.

Sinden, J. W. \& E. Hauser, 1950. Report on two new mushroom diseases. Mushroom Sci. 1: 96-100.

Spradling Chidester, M., 1939. Further studies on temperatures necessary to kill fungi in wood. Proc. Am. Wood Preserv. Ass. 35 : 319-324. 